\title{
Pengaruh Orientasi Etis, Love of money dan Pengalaman Auditor Pada Persepsi
}

Etis Auditor Mengenai Creative accounting

\author{
Pradnya Paramita1 \\ Fakultas Ekonomi dan Bisnis \\ Universitas Udayana, Indonesia \\ Email: pradnyaparamita424@yahoo.com
}

\author{
I Ketut Suryanawa ${ }^{2}$ \\ Fakultas Ekonomi dan Bisnis \\ Universitas Udayana, Indonesia
}

\begin{abstract}
ABSTRAK
Tujuan dari penelitian ini adalah untuk mengetahui pengaruh Orientasi Etis, Love of money, dan Pengalaman Auditor Terhadap Persepsi Etis Auditor mengenai Creative accounting.Penelitian ini dilakukan di seluruh Kantor Akuntan Publik Provinsi Bali pada auditor di tiap KAP. Penelitianini menggunakan teknik analisis regresi linear berganda. Dari hasil perhitungan didapatkan bahwa sampel berjumlah 51 orang responden yang merupakan auditor di tiap Kantor Akuntan Publik Provinsi Bali dan telah menjalani masa kerja minimal 1 tahun. Hasil analisis menunjukkan bahwa Orientasi Etis, Love of money, dan Pengalaman Auditor berpengaruh signifikan pada Persepsi Etis Auditor mengenai Creative accounting.
\end{abstract}

Kata Kunci: Orientasi Etis; Love Of Money; Pengalaman Auditor; Persepsi Etis; Auditor; Creative Accounting.

Effects of Ethical Orientation, Love of money and Auditor's Experience on the Auditor's Ethical Perceptions Regarding Creative accounting

\section{ABSTRACT}

The purpose of this study was to determine the effect of Ethical Orientation, Love of money, and Auditor's Experience on the Auditor's Ethical Perceptions regarding Creative accounting. This research was conducted in all Bali Province Public Accountant Offices on auditors in each KAP. This study uses multiple linear regression analysis techniques. From the calculation results, it was found that a sample of 51 respondents who were auditors at each Bali Province Public Accountant Office and had served a minimum of 1 year of service. The analysis shows that Ethical Orientation, Love of money, and Auditor Experience significantly influence the Auditor's Ethical Perception of Creative accounting.

Keywords: Ethical Orientation; Love Of Money; Auditor Experience; Ethical Perception; Auditor; Creative Accounting.

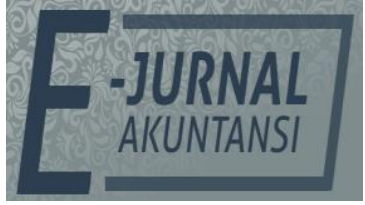

E-JA

e-Jurnal Akuntansi e-ISSN 2302-8556

Vol. 30 No. 6 Denpasar, Juni 2020

Hal.1369-1381

Artikel Masuk: 17 Desember 2019

Tanggal Diterima: 6 Maret 2020

This Article is Avalilable in: $h t t p s: / / o j s . u n u d . a c . i d / i n d e x . p h p / A k u n t a n s i / i n d e x$ 


\section{PENDAHULUAN}

Persepsi Etis adalah pengambilan keputusan terhadap sesuatu dengan ukuran baik dan buruk sesuai dengan asas perilaku yang disepakati secara umum (Foerthiono \& Sadjiarto, 2014). Adanya faktor dalam diri seseorang dan faktor dunia luar dapat mempengaruhi persepsi etis seseorang terhadap permasalahan etika. Wibowo, (2014) menunjukkan bahwa orientasi etis berpengaruh secara signifikan terhadap persepsi etis pada auditor dalam mengenali masalahmasalah etika dan membuat pilihan-pilihan atau pertimbangan etis (ethical judgment) dan dapat mempengaruhi suatu keputusan etis. Hasil penelitian Bulutoding \& Paramitasari, (2014) menyatakan bahwa tingkat kecintaan uang (love of money) Ariyanto et al. (2020) dapat mempengaruhi perilaku etis auditor, yang dimana persepsi etis auditor terhadap permasalahan etika juga ikut terpengaruh. Pada penelitian yang dilakukan oleh Uyar, et al., (2015) menunjukkan bahwa pengalaman kerja berpengaruh terhadap kesadaran etis yang mempengaruhi persepsi etis auditor terhadap suatu permasalahan etika.

Orientasi etis mencerminkan cara pandang seseorang dalam memberikan tanggapan atas suatu perilaku etis atau tidak etis (Mardawati, 2016). Orientasi etika atau nilai-nilai etika dikendalikan oleh dua karakteristik yaitu idealisme dan relativisme (Forsyth, 1980). Seorang individu yang idealis akan menghindari berbagai tindakan yang dapat menyakiti maupun merugikan orang disekitarnya. Seorang individu relativisme tidak akan mengindahkan prinsip-prinsip yang ada dan lebih melihat keadaan sekitar sebelum akhirnya bertindak merespon suatu kejadian yang melanggar etika (Fitria, 2015). Hasil penelitian Widiastuti \& Nugroho, (2015), serta Apriliawati \& Suardana, (2016) menyatakan bahwa orientasi idealisme berpengaruh positif secara signifikan terhadap persepsi etis, yang berarti semakin tinggi tingkat idealisme yang dimiliki seorang auditor maka akan meningkatkan persepsi etisnya, sehingga akan lebih mengarah pada pedoman yang telah ditetapkan dan dapat berprilaku etis. Orientasi relativisme berpengaruh negatif pada pertimbangan etis, yang berarti auditor yang mempunyai tingkat relativisme yang tinggi cenderung menolak aturan-aturan moral, sehingga persepsi etisnya rendah dan cenderung berprilaku tidak etis. Namun, perbedaan hasil didapat dari penelitian Mardawati, (2016) yang menyatakan bahwa orientasi idealisme berpengaruh negatif secara signifikan terhadap persepsi etis. Dengan adanya beberapa hasil penelitian tersebut, membuat peneliti menggunakan orientasi etis sebagai variabel bebas karena dengan adanya orientasi etika menunjukkan pandangan yang diadopsi oleh masing-masing individu ketika menghadapi situasi masalah yang membutuhkan pemecahan dan penyelesaian etika.

Uang merupakan aspek yang sangat penting di dalam kehidupan seharihari. Harun (2016) dan Ariyanto et al. (2020) mendefinisikan love of money sebagai perilaku seseorang terhadap uang, pengertian seseorang terhadap uang, serta keinginan dan aspirasi seseorang terhadap uang. Love of money mengukur seberapa jauh kecintaan seseorang kepada uang yang akan berpengaruh pada persepsi etisnya Ariyanto et al. (2020). Semakin tinggi tingkat love of money seseorang maka semakin rendah persepsi etisnya (Pradanti \& Prastiwi, 2014). Hasil penelitian sebelumnya oleh Pradanti \& Prastiwi, (2014) serta Hermawan \& Nurlia, (2017) menyimpulkan bahwa love of money (kecintaan uang) seseorang 
berpengaruh negatif terhadap pertimbangan dan persepsi etisnya. Hal tersebut menunjukkan semakin tinggi love of money semakin rendah persepsi etis individu. Namun, perbedaan hasil penelitian diperoleh pada penelitian Mulyani, (2015) dan Ariyanto et al. (2020) menyatakan bahwa love of money berpengaruh positif terhadap persepsi etis, yang menunjukkan bahwa individu dengan love of money yang akan semakin tinggi juga persepsi etisnya. Dengan adanya beberapa hasil penelitian tersebut, membuat peneliti menggunakan love of money sebagai variabel bebas karena sikap love of money yang ada pada diri seseorang akan membentuk suatu perilaku yang menunjukkan bagaimana karakter orang tersebut terhadap uang.

Pengalaman merupakan suatu proses pembelajaran dan pertambahan perkembangan potensi bertingkah laku baik dari pendidikan formal maupun non formal (Dewi \& Wirakusuma, 2018). Dalam bidang auditing pengalaman merupakan salah satu elemen penting disamping pengetahuan yang juga harus dimiliki seseorang yang dianggap ahli oleh masyarakat untuk melakukan pemeriksaan pada suatu perusahaan ataupun instansi. Semakin banyaknya pengalaman yang dihadapi selama hidup, akan meningkatkan nilai moral (Malia, 2010). Hasil penelitian yang dilakukan oleh Dewi \& Wirakusuma, (2018) serta Uyar, et al., (2015) menunjukkan bahwa pengalaman kerja berpengaruh positif terhadap kesadaran etis yang dimiliki pada auditor. Namun, perbedaaan penelitian diperoleh pada temuan Sasongko, et al., (2007) yang dalam penelitiannya tidak ditemukan pengaruh pengalaman audit baik dalam hubungannya dengan pengambilan keputusan etis. Dengan adanya beberapa hasil penelitian tersebut, membuat peneliti menggunakan pengalaman sebagai variabel bebas karena melalui pengalaman dapat membentuk karakter seseorang berdasarkan apa yang diperoleh yang baik maupun buruk.

Berbagai hasil penelitian yang menunjukkan adanya perbedaan persepsi etis mengenai creative accounting perlu kiranya untuk mengetahui bagaimana pandangan auditor terhadap persoalan etika, yang dalam hal ini mengacu pada praktik creative accounting yang mungkin sudah ataupun yang akan dihadapi nanti, mengingat persepsi etis auditor memainkan peran penting dalam pengambilan keputusan etis serta dalam perilaku auditor dalam menghadapi persoalan etika (Wibowo, 2014). Auditor yang memiliki tingkat idealisme yang tinggi akan cenderung mengikuti aturan moral serta lebih mengarah pada pedoman yang telah ditetapkan. Sedangkan auditor apabila memiliki tingkat idealisme yang rendah akan cenderung menentang aturan moral, maka pandangan auditor pada persepsi etis akan semakin meningkat Apriliawati \& Suardana, (2016).

Hasil penelitian sebelumnya oleh Widiastuti \& Nugroho, (2015) serta penelitian Apriliawati \& Suardana, (2016) mengungkapkan bahwa Orientasi Idealisme berpengaruh positif terhadap perilaku etis auditor, sehingga meningkatkan persepsi etis auditor terhadap persoalan etika. Hal tersebut sejalan dengan penelitian Douglas, et al., (2001) yang juga meneliti hubungan antara orientasi etis dan pertimbangan etis auditor, menunjukkan hasil bahwa mempunyai derajat idealisme yang lebih tinggi akan berhubungan dengan keputusan yang lebih etis terhadap masalah etika. Menurut penelitian yang dilakukan oleh Baharuddin, \& Satyanugraha, (2004) mengenai faktor-faktor yang 
mempengaruhi persepsi profesi akuntan terhadap praktik earning management, hasilnya menunjukkan bahwa terdapat peranan positif dari orientasi etika individu terhadap persepsi tentang perilaku moral praktik earnings management. Dari berbagai hasil penelitian tersebut, menunjukkan auditor yang berorientasi idealisme akan meningkatkan persepsi etisnya terhadap permasalahan etika dan selalu berpedoman pada aturan yang berlaku, sehingga akan menilai praktek creative accounting yang sifatnya negatif merupakan hal yang tidak etis dan dapat merugikan orang lain, dengan kata lain auditor yang memiliki idealisme yang tinggi cenderung memberikan tanggapan negatif terhadap skandal akuntan yang berarti persepsi etis auditor mengenai praktek creative accounting akan semakin meningkat. Berdasarkan uraian tersebut, maka dapat dirumuskan hipotesis sebagai berikut:

$\mathrm{H}_{1}$ : Orientasi etis idealisme berpengaruh positif terhadap persepsi etis auditor mengenai praktek creative accounting.

Di sisi lain, individu yang relativis justru tidak mengindahkan prinsipprinsip yang ada dan lebih melihat keadaan sekitar sebelum akhirnya bertindak atau merespon suatu kejadian yang melanggar etika. Relativisme etis berbicara tentang pengabaian prinsip dan tidak adanya rasa tangggung jawab dalam pengalaman hidup seseorang. Mahasiswa yang memiliki relativisme yang tinggi cenderung memberikan presepsi positif terhadap suatu skandal yang terjadi di dalam profesi yang berkaitan dengan akuntansi, sehingga relativisme akan setuju terhadap praktik creative accounting. Relativisme akan berpengaruh terhadap Persepsi Mahasiswa mengenai Praktik Creative accounting (Anggita, 2017).

Hal ini sejalan dengan penelitian yang dilakukan oleh Liu, (2006) yang menyatakan bahwa pemikiran relativisme mengarahkan tindakan seseorang sesuai dengan apa yang dia persepsikan secara pribadi, sehingga keputusan yang mereka buat seringkali bertentangan dengan norma yang umumnya ada di masyarakat. Pada penelitian Widiastuti \& Nugroho, (2015) serta penelitian Apriliawati \& Suardana, (2016) juga menyatakan bahwa orientasi relativisme mengarahkan seseorang bertindak sesuai persepsi pribadinya dan cenderung melanggar norma yang berlaku, sehingga kurang tanggap terhadap permasalahan etika. Hal tersebut menunjukkan auditor yang berorientasi relativisme akan menganggap praktek creative accounting merupakan hal yang etis dan sah - sah saja untuk dilakukan, walaupun tindakan tersebut dapat merugikan orang lain. Dengan kata lain, semakin tinggi sikap relativisme auditor akan cenderung memberikan tanggapan negatif terhadap skandal akuntan yang berarti persepsi etis auditor mengenai praktek creative accounting akan semakin menurun. Berdasarkan uraian tersebut, maka dapat dirumuskan hipotesis sebagai berikut :

$\mathrm{H}_{2}$ : Orientasi etis relativisme berpengaruh negatif terhadap persepsi etis auditor mengenai praktek creative accounting.

Tang \& Chiu, (2002) menyatakan bahwa orang-orang dengan orientasi love of money yang tinggi memiliki kepuasaan rendah dengan gaji. Pada penelitian Basri, (2015) menjelaskan bahwa orang-orang dengan perilaku cinta uang atau money ethic yang tinggi akan menempatkan kepentingan yang besar pada uang akan kurang etis dan sensitif daripada orang dengan money ethic 
rendah. Pada penelitian Pradanti \& Prastiwi, (2014) serta Hermawan \& Nurlia, (2017) yang menyatakan bahwa love of money berpengaruh negatif terhadap pertimbangan/persepsi etis, yang artinya sikap seseorang yang memiliki sikap cinta uang berlebih akan cenderung memandang uang sebagai suatu kebutuhan dan berambisi untuk memeperolehnya dengan berbagai cara, dan dapat dipatika bahwa orang tersebut memiliki persepsi etis yang rendah. Mulyani, (2015) mengatakan bahwa kecintaan seseorang terhadap uang dapat mengakibatkan seseorang lupa diri dengan nilai-nilai etika dan moral yang dimilikinya. Hasil penelitian tersebut didukung oleh penelitian dalam negeri yang dilakukan Pradanti \& Prastiwi, (2014) serta Yeltsinta, et al., (2013) yang menyatakan bahwa love of money berpengaruh negatif terhadap pertimbangan/persepsi etis. Dari hal tersebut dapat disimpulkan bahwa auditor yang memiliki tingkat love of money yang tinggi cenderung memiliki persepsi yang rendah mengenai persoalan etika, termasuk creative accounting. Berdasarkan uraian tersebut, maka dapat dirumuskan hipotesis sebagai berikut:

$\mathrm{H}_{3}$ : Love of money berpengaruh negatif terhadap persepsi etis auditor mengenai praktek creative accounting.

Berdasarkan Theory of Planned Behavior, pengalaman berkaitan dengan Perceived behavioral control. Pengalaman dapat membentuk karakter seseorang berdasarkan apa yang diperoleh seseorang, sehingga karakter tersebut akan memunculkan suatu keyakinan (belief), Keyakinan-keyakinan ini akan memunculkan suatu persepsi dalam diri seseorang mengenai suatu perilaku.

Hasil penelitian sebelumnya, yaitu penelitian yang dilakukan oleh Malia, (2010) juga menunjukkan bahwa pengalaman akuntan meengaruhi persepsi etis akuntan mengenai praktek manajemen laba, sebagai bagian dari creative accounting. Akuntan yang memiliki pengetahuan yang tinggi serta pengalaman yang matang akan mampu menilai setiap masalah etika yang sedang dihadapinya dengan kritis, begitu juga dengan praktek manajemen laba yang menimbulkan dampak merugikan bagi pihak lain. Tahar, (2012) menunjukkan bahwa ketika akuntan pemeriksa menjadi lebih berpengalaman maka auditor menjadi sadar terhadap lebih banyak kekeliruan yang terjadi, dan memiliki salah pengertian yang lebih sedikit mengenai kekeliruan yang tidak lazim serta lebih menonjoldalam menganalisa hal-hal yang berkaitan dengan penyebab kekeliruan. Mudassir, (2016) dalam penelitiannya yang berjudul "Pengaruh Pengalaman Audit Terhadap Pengambilan Keputusan Etis Dengan Budaya Organisasi Sebagai Pemoderasi" menunjukkan bahwa Auditor APIP yang memiliki pengalaman audit yang tinggi mampu melakukan pengambilan keputusan etis. Pengalaman waktu berkembang seiring bertambahnya masa kerja sebagai auditor. Sedangkan, pengalaman kerja berkembang melalui berbagai jenis penugasan, memberikan peluang auditor APIP untuk semakin trampil dalam melakukan pekerjaan dan semakin sempurna pola berpikir dan bersikap dalam bertindak. Mustika \& Jati, (2017) yang meneliti tentang "Pengaruh Pengalaman, Komitmen Profesional, Komitmen Organisasional, Idealisme, Dan Relativisme Pada Etika Auditor" menunjukkan bahwa pengalaman berpengaruh positif pada etika auditor Kantor Akuntan Publik di Bali. Hal ini memiliki makna bahwa auditor yang berpengalaman akan memiliki tingkat etika yang baik. Dari hal tersebut dapat disimpulkan, bahwa auditor 
yang semakin berpengalaman akan maka akan semakin etis keputusan yang diambilnya terhadap masalah creative accounting.

Berdasarkan hal tersebut, keterkaitan antara pengalaman akuntan dengan persepsi etis tentang praktik manajemen laba dapat dirumuskan dengan hipotesis sebagai berikut:

$\mathrm{H}_{4}$ : Pengalaman auditor berpengaruh positif terhadap persepsi etis auditor mengenai praktek creative accounting.

\section{METODE PENELITIAN}

Penelitian ini dilakukan pada auditor di Kantor Akuntan Publik di Bali. Berdasarkan Direktori Kantor Akuntan Publik dari Institut Akuntan Publik Indonesia terdapat 13 Kantor Akuntan Publik di Bali. Waktu penelitian ini dilakukan pada tahun 2019. Adapun yang menjadi populasi dalam penelitian ini adalah seluruh auditor pada Kantor Akuntan Publik di Provinsi Bali yang terdaftar dalam Direktori yang diterbitkan oleh Institut Akuntan Publik Indonesia (IAPI) tahun 2019. Teknik pengambilan sampel yang digunakan dalam penelitian ini adalah purposive sampling, dengan kriteria auditor yang menjadi sampel adalah auditor yang pernah memiliki pengalaman dalam melakukan pemeriksaan audit dan pernah ditugaskan dalam pekerjaan lapangan minimal 1 tahun. Alasan kriteria tersebut peneliti menganggap telah memiliki pemahaman yang cukup mengenai penugasan audit yang diberikan serta mampu menyesuaikan dengan lingkungan pekerjaan dan telah memperoleh tugas sebagai junior auditor. Auditor yang digunakan sebagai responden tidak dibatasi oleh jabatan di Kantor Akuntan Publik baik sebagai partner, senior, ataupun junior auditor. Alasan penggunaan responden yang tidak dibatasi oleh jabatan dilakukan dengan pertimbangan bahwa setiap auditor yang bekerja pada kantor akuntan publik melakukan proses audit yaitu melakukan pemeriksaan terhadap laporan keuangan dan memberikan pendapat serta mengambil keputusankeputusan atas dasar hasil pemeriksaan tersebut (Sari \& Sudana, 2013). Berdasarkan kriteria tersebut, maka diperoleh sampel sejumlah 45 auditor.

Analisis regresi linear berganda digunakan untuk mengetahui pengaruh beberapa variabel independen terhadap variabel dependen. Analisis ini untuk mengetahui arah hubungan antara variabel independen dengan variabel dependen, apakah masing-masing variabel independen berhubungan positif atau negatif. Adapun model rumus yang digunakan adalah sebagai berikut :

$$
Y=\alpha+\beta_{1} X_{1}+\beta_{2} X_{2}+\beta_{3} X_{3}+\beta_{4} X_{4}+\varepsilon
$$

Keterangan:

$$
\begin{aligned}
& \mathrm{Y} \quad=\text { Persepsi Etis Auditor Mengenai Creative accounting } \\
& \text { a } \quad=\text { Konstanta } \\
& \beta_{1}-\beta_{3} \quad=\text { Koefisien regresi } \\
& \mathrm{X}_{1} \quad=\text { Orientasi Etis Idealisme } \\
& \mathrm{X}_{2} \quad=\text { Orientasi Etis Relativisme } \\
& \mathrm{X}_{3} \quad=\text { Love of money } \\
& \mathrm{X}_{4} \quad=\text { Pengalaman Akuntan } \\
& \varepsilon \quad=\text { Error Term, yaitu tingkat kesalahan penduga dalam penelitian }
\end{aligned}
$$




\section{HASIL DAN PEMBAHASAN}

Perhitungan koefisien regresi linier berganda dilakukan dengan analisis regresi melalui software SPSS 18.0 for Windows, diperoleh hasil yang ditunjukan pada Tabel 1.

Tabel 1. Hasil Analisis Regresi Linier Berganda

\begin{tabular}{|c|c|c|c|c|c|c|}
\hline & Model & $\begin{array}{r}\text { Unstand } \\
\text { Coeffic }\end{array}$ & $\begin{array}{l}\text { ardized } \\
\text { cients }\end{array}$ & $\begin{array}{c}\text { Standardized } \\
\text { Coefficients }\end{array}$ & & \\
\hline & & $B$ & Std. Error & Beta & $\mathrm{T}$ & Sig. \\
\hline$\overline{1}$ & (Constant) & 22.734 & 5.619 & & 4.046 & .000 \\
\hline & Orientasi Etis Idealisme & .402 & .149 & .266 & 2.706 & .010 \\
\hline & Orientasi Etis Relativisme & -.649 & .190 & -.332 & -3.423 & .001 \\
\hline & Love of money & -.294 & .090 & -.342 & -3.264 & .002 \\
\hline & Pengalaman Auditor & .479 & .145 & .345 & 3.299 & .002 \\
\hline & $\begin{aligned} & =0,000 \\
t e d R^{2} & =0540\end{aligned}$ & & & & & \\
\hline & ted $R^{2} \quad \begin{aligned} &=0,540 \\
&=0,000\end{aligned}$ & & & & & \\
\hline
\end{tabular}

Berdasarkan hasil analisis regresi linier berganda seperti yang disajikan pada Tabel 1. maka dapat dibuat persamaan regresi sebagai berikut:

$$
Y=22,734+0,402 X_{1}-0,649 X_{2}-0,294 X_{3}+0,479 X_{4}
$$

Nilai konstanta (a) sebesar 22,734 memiliki arti jika variabel orientasi etis idealisme $\left(\mathrm{X}_{1}\right)$, orientasi etis relativisme $\left(\mathrm{X}_{2}\right)$, love of money $\left(\mathrm{X}_{3}\right)$, dan pengalaman auditor $\left(\mathrm{X}_{4}\right)$ dinyatakan konstan pada angka 0, maka nilai Persepsi Etis Auditor mengenai Creative accounting $(\mathrm{Y})$ sebesar 1,458 berarah positif. Nilai koefisien $\mathrm{X}_{1}$ pada variabel orientasi etis idealisme sebesar 0,402 dengan arah koefisien regresi yang bernilai positif. Hal ini menunjukkan apabila nilai orientasi etis idealisme meningkat sebesar satu satuan maka Persepsi Etis Auditor mengenai Creative accounting (Y) akan meningkat sebesar 0,402 dengan asumsi variabel lain konstan. Nilai koefisien $X_{2}$ pada variabel orientasi etis relativisme sebesar 0,649 dengan arah koefisien regresi yang bernilai negatif. Hal ini menunjukkan apabila nilai orientasi etis relativisme menurun sebesar satu satuan maka Persepsi Etis Auditor mengenai Creative accounting $(\mathrm{Y})$ akan menurun sebesar 0,649 dengan asumsi variabel lain konstan. Orientasi Etis Relativisme berpengaruh negatif terhadap Persepsi Etis Auditor mengenai Creative accounting. Artinya semakin tinggi orientasi etis relativisme maka semakin rendah Persepsi Etis Auditor mengenai Creative accounting. Nilai koefisien $X_{3}$ pada variabel love of money sebesar 0,294 dengan arah koefisien regresi yang bernilai negatif. Hal ini menunjukkan apabila nilai love of money menurun sebesar satu satuan maka Persepsi Etis Auditor mengenai Creative accounting (Y) akan menurun sebesar 0,294 dengan asumsi variabel lain konstan. Love of money berpengaruh negatif terhadap Persepsi Etis Auditor mengenai Creative accounting. Artinya semkin tinggi love of money pada auditor maka semakin rendah Persepsi Etis Auditor mengenai Creative accounting.Nilai koefisien $\mathrm{X}_{4}$ pada variabel pengalaman auditor sebesar 0,479 dengan arah koefisien regresi yang bernilai positif. Hal ini menunjukkan apabila nilai pengalaman auditor meningkat sebesar satu satuan maka Persepsi Etis Auditor mengenai Creative accounting (Y) akan meningkat sebesar 0,479 dengan asumsi variabel lain konstan. 
Koefisien determinasi $\left(\mathrm{R}^{2}\right)$ digunakan untuk mengetahui dan mengukur kemampuan model dalam menerangkan variasi variabel independen. Besarnya pengaruh variabel bebas terhadap variabel terikat yang ditunjukkan oleh nilai determinasi total (Adjusted R Square).

Tabel 1. menunjukkan nilai Adjusted R Square sebesar 0,540 mempunyai arti bahwa sebesar 54\% variasi Persepsi Etis Auditor mengenai Creative accounting pada KAP Provinsi Bali dipengaruhi oleh variasi Orientasi Etis Idealisme, Orientasi Etis Relativisme, Love of money, dan Pengalaman Auditor, sedangkan sisanya sebesar $46 \%$ djelaskan oleh faktor lain yang tidak dimasukkan ke dalam model.

Uji kelayakan model (uji F) bertujuan untuk menguji apakah semua variabel Orientasi Etis Idealisme, Orientasi Etis Relativisme, Love of money, dan Pengalaman Auditor berpengaruh terhadap variabel Persepsi Etis Auditor mengenai Creative accounting dan untuk mengetahui model regresi yang digunakan dalam penelitian ini layak diuji atau tidak. Adapun hasil uji kelayakan model dalam penelitian ini disajikan pada Tabel 1.

Hasil pengolahan data pada Tabel 1. dengan menggunakan program SPSS diperoleh nilai $F_{\text {hitung }}$ sebesar 15,646 dengan signifkansi sebesar 0,000<0,05, maka dapat disimpulkan bahwa pada kelompok yang diuji memiliki perbedaan yang nyata (signifikan). Hasil ini mempunyai arti bahwa secara simultan Orientasi Etis Idealisme, Orientasi Etis Relativisme, Love of money, dan Pengalaman Auditorberpengaruh signifikan terhadap Persepsi Etis Auditor mengenai Creative accounting pada KAP di Provinsi Bali.

Pengaruh variabel Orientasi Etis Idealisme, Orientasi Etis Relativisme, Love of money, dan Pengalaman Auditorterhadap Persepsi Etis Auditor mengenai Creative accounting diuji dengan menggunakan Uji t. Kriteria pengujian untuk menjelaskan interpretasi pengaruh antar masing-masing variabel yakni apabila nilai signifikansi $<0,05$ maka $\mathrm{H}_{0}$ ditolak dan $\mathrm{H}_{1}$ diterima. Sebaliknya, jika nilai signifikansi $>0,05$ maka $\mathrm{H}_{0}$ diterima dan $\mathrm{H}_{1}$ ditolak. Adapun penjelasan pengaruh masing-masing variabel dapat dijelaskan sebagai berikut:

Berdasarkan hasil analisis pengaruh Orientasi Etis Idealisme terhadap Persepsi Etis Auditor mengenai Creative accounting diperoleh nilai signifikasi sebesar 0,010 dengan nilai koefisien regresi positif sebesar 0,402. Nilai Signifikansi $0,010<0,05$ mengindikasikan bahwa $\mathrm{H}_{1}$ diterima. Hasil ini mempunyai arti bahwa Orientasi Etis Idealisme berpengaruh positif dan signifikan terhadap Persepsi Etis Auditor mengenai Creative accounting. Berdasarkan hasil analisis pengaruh Orientasi Etis Relativisme terhadap Persepsi Etis Auditor mengenai Creative accounting diperoleh nilai signifikansi sebesar 0,001 dengan nilai koefisien regresi negatif sebesar -0,649. Nilai Signifikansi $0,001<0,05$ mengindikasikan bahwa $\mathrm{H}_{2}$ diterima. Hasil ini mempunyai arti bahwa Orientasi Etis Relativisme berpengaruh negatif dan signifikan terhadap Persepsi Etis Auditor mengenai Creative accounting. Berdasarkan hasil analisis pengaruh Love of money terhadap Persepsi Etis Auditor mengenai Creative accounting diperoleh nilai signifikansi sebesar 0,002 dengan nilai koefisien regresi negatif sebesar -0,294. Nilai signifikansi $0,002<0,05$ mengindikasikan bahwa $\mathrm{H}_{3}$ diterima. Hasil ini mempunyai arti bahwa Love of moneyberpengaruh negatif dan signifikan Persepsi Etis Auditor mengenai Creative accounting. Berdasarkan hasil 
analisis pengaruh Pengalaman Auditor terhadap Persepsi Etis Auditor mengenai Creative accounting diperoleh nilai signifikansi sebesar 0,002 dengan nilai koefisien regresi positif sebesar 0,479. Nilai signifikansi 0,002 $<0,05$ mengindikasikan bahwa $\mathrm{H}_{4}$ diterima. Hasil ini mempunyai arti bahwa Pengalaman Auditor berpengaruh positif dan signifikan terhadap Persepsi Etis Auditor mengenai Creative accounting.

Hasil penelitian menunjukkan bahwa $\beta_{1}=0,402$ dengan tingkat signifikan sebesar 0,010 yang lebih kecil dari taraf nyata dalam penelitian ini, yaitu 0,05 artinya Orientasi Etis Idealisme berpengaruh positif dan signifikan pada Persepsi Etis Auditor mengenai Creative accounting, maka hipotesis pertama $\left(\mathrm{H}_{1}\right)$ diterima. Hasil penelitian ini juga sejalan dengan temuan Widiastuti \& Nugroho, (2015)serta penelitian Apriliawati \& Suardana, (2016)yang mengungkapkan bahwa Orientasi Idealisme berpengaruh positif terhadap perilaku etis auditor, yaitu auditor yang memiliki tingkat idealisme yang tinggi akan cenderung mengikuti aturan moral serta lebih mengarah pada pedoman yang telah ditetapkan. Sedangkan auditor apabila memiliki tingkat idealisme yang rendah akan cenderung menentang aturan moral, maka persepsi etis auditor pada persepsi etis akan semakin rendah.

Hasil penelitian menunjukkan bahwa $\beta_{2}=-0,649$ dengan tingkat signifikan sebesar 0,001 yang lebih kecil dari taraf nyata dalam penelitian ini, yaitu 0,05 artinya Orientasi Etis Relativisme berpengaruh negatif dan signifikan pada Persepsi Etis Auditor mengenai Creative accounting, maka hipotesis kedua $\left(\mathrm{H}_{2}\right)$ diterima. Hal ini berarti bahwa semakin tinggi persepsi etis relativisme yang dimiliki auditor, maka akan cenderung memberikan presepsi yang rendah terhadap suatu skandal yang terjadi di dalam profesi yang berkaitan dengan akuntansi, sehingga relativisme akan menilai praktik creative accounting merupakan hal yang etis. Hal ini sejalan dengan penelitian yang dilakukan oleh Liu, (2006) yang menyatakan bahwa pemikiran relativisme mengarahkan tindakan seseorang sesuai dengan apa yang dia persepsikan secara pribadi, sehingga keputusan yang mereka buat seringkali bertentangan dengan norma yang umumnya ada di masyarakat. Hasil penelitian ini juga mendukung temuan Widiastuti \& Nugroho, (2015), Apriliawati \& Suardana, (2016) serta Anggita, (2017) yang menyatakan bahwa orientasi relativisme mengarahkan seseorang bertindak sesuai persepsi pribadinya dan cenderung melanggar norma yang berlaku, sehingga kurang tanggap terhadap permasalahan etika.

Hasil penelitian menunjukkan bahwa $\beta_{3}=-0,294$ dengan tingkat signifikan sebesar 0,002 yang lebih kecil dari taraf nyata dalam penelitian ini, yaitu 0,05 artinya Love of money berpengaruh negatif dan signifikan pada Persepsi Etis Auditor mengenai Creative accounting, maka hipotesis ketiga $\left(\mathrm{H}_{3}\right)$ diterima. Hal ini berarti bahwa semakin tinggi sikap Love of money auditor maka akan berpengaruh pada semakin rendahnya Persepsi Etis Auditor mengenai Creative accounting. Begitu pula sebaliknya, semakin rendah sikap Love of money maka akan berpengaruh pada semakin meningkatnya Persepsi Etis Auditor mengenai Creative accounting. Hasil ini sesuai dengan Teori Kebutuhan dan Kepuasan, yang menyatakan bahwa tingkat love of money berkaitan dengan pemenuhan kebutuhan seseorang. Kebutuhan tersebut mencakup kebutuhan dari yang paling mendasar hingga kebutuhan ke tingkat yang lebih tinggi. Untuk 
memenuhi kebutuhan tersebutlah yang mendorong seseorang berperilaku tidak etis. Hal tersebut mencerminkan persepsi etis orang tersebut rend ah terhadap permasalahan etika.

Temuan penelitian ini konsisten dengan penelitian Basri, (2015) yang menjelaskan bahwa orang-orang dengan perilaku cinta uang atau money ethic yang tinggi akan menempatkan kepentingan yang besar pada uang akan kurang etis dan sensitif daripada orang dengan money ethic rendah. Hal tersebut sejalan dengan penelitian Pradanti \& Prastiwi, (2014) serta Hermawan \& Nurlia, (2017) yang menyatakan bahwa love of money berpengaruh negatif terhadap pertimbangan atau persepsi etis, yang artinya sikap seseorang yang memiliki sikap cinta uang berlebih akan cenderung memandang uang sebagai suatu kebutuhan dan berambisi untuk memeperolehnya dengan berbagai cara, dan dapat dipastikan bahwa orang tersebut memiliki persepsi etis yang rendah. Selain itu, hasil penelitian ini juga mendukung penelitian Yeltsinta, et al.,(2013), Pradanti \& Prastiwai, (2014), serta Mulyani, (2015) yang menyatakan bahwa love of money berpengaruh negatif terhadap pertimbangan/persepsi etis. Dari hal tersebut dapat disimpulkan bahwa auditor yang memiliki tingkat love of money yang tinggi cenderung memiliki persepsi yang rendah mengenai persoalan etika, termasuk creative accounting.

Hasil penelitian menunjukkan bahwa $\beta_{4}=0,479$ dengan tingkat signifikan sebesar 0,002 yang lebih kecil dari taraf nyata dalam penelitian ini, yaitu 0,05 artinya Orientasi Etis Idealisme berpengaruh positif dan signifikan pada Persepsi Etis Auditor mengenai Creative accounting, maka hipotesis keempat $\left(\mathrm{H}_{4}\right)$ diterima. Hal ini berarti bahwa semakin tinggi Pengalaman Auditor maka Persepsi Etis Auditor mengenai Creative accounting juga akan semakin meningkat. Ini berarti bahwa Auditor APIP yang memiliki pengalaman audit yang tinggi mampu melakukan pengambilan keputusan etis. Pengalaman waktu berkembang seiring bertambahnya masa kerja sebagai auditor. Sedangkan, pengalaman kerja berkembang melalui berbagai jenis penugasan, memberikan peluang auditor APIP untuk semakin trampil dalam melakukan pekerjaan dan semakin sempurna pola berpikir dan bersikap dalam bertindak.

Hasil penelitian ini sesuai dengan Theory of Planned Behavior, yang menyatakan bahwa pengalaman berkaitan dengan Perceived behavioral control. Pengalaman dapat membentuk karakter seseorang berdasarkan apa yang diperoleh seseorang, sehingga karakter tersebut akan memunculkan suatu keyakinan (belief), Keyakinan-keyakinan ini akan memunculkan suatu persepsi dalam diri seseorang mengenai suatu perilaku.

Penelitian ini konsisten dengan hasil penelitian yang dilakukan oleh Malia, (2010) yang menunjukkan bahwa pengalaman akuntan meengaruhi persepsi etis akuntan mengenai praktek manajemen laba, sebagai bagian dari creative accounting. Akuntan yang memiliki pengetahuan yang tinggi serta pengalaman yang matang akan mampu menilai setiap masalah etika yang sedang dihadapinya dengan kritis, begitu juga dengan praktek manajemen laba yang menimbulkan dampak merugikan bagi pihak lain. Hasil penelitian ini mendukung temuan Tahar, (2012) menunjukkan bahwa ketika akuntan pemeriksa menjadi lebih berpengalaman maka auditor menjadi sadar terhadap lebih banyak kekeliruan yang terjadi, dan memiliki salah pengertian yang lebih 
sedikit mengenai kekeliruan yang tidak lazim serta lebih menonjoldalam menganalisa hal-hal yang berkaitan dengan penyebab kekeliruan. Selain itu, hasil ini juga sesuai dengan penelitian Mudassir, (2016), serta Mustika \& Jati, (2017) yang menunjukkan bahwa pengalaman berpengaruh positif pada etika auditor Kantor Akuntan Publik di Bali. Hal ini memiliki makna bahwa auditor yang berpengalaman akan memiliki tingkat etika yang baik. Dari hal tersebut dapat disimpulkan, bahwa auditor yang semakin berpengalaman akan maka akan semakin etis keputusan yang diambilnya terhadap masalah creative accounting.

\section{SIMPULAN}

Orientasi Etis Idealisme berpengaruh positif dan signifikan terhadap Persepsi Etis Auditor mengenai Creative accounting. Hal ini berarti bahwa semakin tinggi persepsi etis idealisme, maka akan meningkatkan persepsi etis auditor terhadap permasalahan etika dan pada akhirnya cenderung menolak atau memberikan tanggapan atas ketidaksetujuan pada praktik creative accounting. Orientasi Etis Relativisme berpengaruh negatif dan signifikan terhadap Persepsi Etis Auditor mengenai Creative accounting. Hal ini berarti bahwa semakin tinggi persepsi etis relativisme yang dimiliki auditor, maka akan cenderung memberikan presepsi positif terhadap suatu skandal yang terjadi di dalam profesi yang berkaitan dengan akuntansi, sehingga relativisme akan setuju terhadap praktik creative accounting. Love of money berpengaruh negatif dan signifikan terhadap Persepsi Etis Auditor mengenai Creative accounting. Hal ini berarti bahwa semakin tinggi sikap Love of money auditor maka akan berpengaruh pada rendahnya Persepsi Etis Auditor mengenai Creative accounting.Pengalaman Auditor berpengaruh positif dan signifikan terhadap Persepsi Etis Auditor mengenai Creative accounting. Hal ini berarti bahwa semakin tinggi Pengalaman Auditor maka akan mampu melakukan pengambilan keputusan etis, sehingga memberikan peluang auditor untuk semakin trampil dalam melakukan pekerjaan dan pada akhirnya cenderung meningkatkan praktik creative accounting.

\section{REFERENSI}

Anggita, M. Y. C. (2017). Pengaruh Orientasi Etis, Tingkat Pengetahuan Akuntansi dan Jenis Perguruan Tinggi terhadap Persepsi Etis Mahasiswa Akuntansi mengenai Praktik Creative Accounting. Skripsi. Sarjana Jurusan Akuntansi Fakultas Ekonomi Universitas Negeri Yogyakarta.

Apriliawati, N. K., \& Suardana, K. A. (2016). Budaya Etis Organisasi sebagai Variabel Pemoderasi Pengaruh Orientasi Etis pada Pertimbangan Etis Auditor. E-Jurnal Akuntansi Universitas Udayana, 17(2), 1226-1253.

Ariyanto, D., Andayani, G. W., \& Putri, I. G. A. P. (2020). Influence of Justice, Culture and Love of Money Towards Ethical Perception on Tax Evasion with Gender as Moderating Variable. Journal of Money Laundering Control, 23(1), 245-266. https://doi.org/10.1108/JMLC-06-2019-0047

Baharuddin, Ishar Satyanugraha, H. (2004). Faktor-Faktor yang Mempengaruhi Persepsi Profesi Akuntan terhadap Praktek Earnings Management. Media Riset Akuntansi, Auditing \& Informasi.

Basri, Y. M. (2015). Pengaruh Gender, Religiusitas Dan Sikap Love of Money 
Pada Persepsi Etika Penggelapan Pajak Mahasiswa Akuntasi. Jurnal Ilmiah Akuntansi Dan Bisnis, 10(1), 45-54.

Bulutoding, Lince, Rika Dwi Ayu Paramitasari, F. H. (2014). Pengaruh Sifat Machiavellian Dan Love of Money Terhadap Perilaku Etis Auditor. Jurnal Akuntansi Peradaban, 3(2), 65-83.

Dewi, T. K., \& Wirakusuma, M. G. (2018). Pengaruh Kecerdasan Intelektual, Kecerdasan Emosional Dan Kecerdasan Spritual Pada Perilaku Etis Dengan Pengalaman Sebagai Variabel Pemoderasi. E-Jurnal Ekonomi Dan Bisnis Universitas Udayana, 7(9), 2089-2116.

Douglas, P. C., Davidson, R. A., \& Schwartz, B. N. (2001). The Effect of Organizational Culture and Ethical Orientation on Accountans' Ethical Judgments. Journal of Business Ethics, 34, 101-121.

Fitria, M. (2015). Pengaruh Orientasi Idealisme, Relativisme, Tingkat Pengetahuan Akuntansi, dan Gender terhadap Persepsi Mahasiswa Akuntansi tentang Krisis Etika Akuntan Profesional. Skripsi. Sarjana Jurusan Akuntansi Fakultas Ekonomi Universitas Negeri Padang.

Foerthiono, A. N., \& Sadjiarto, R. A. (2014). Faktor-faktor yang Mempengaruhi Minat Mahasiswa Akuntansi Berkarir Sebagai Akuntan Publik dengan Persepsi Etis Skandal Akuntansi Sebagai Variabel Intervening. Tax $\mathcal{E}$ Accounting Review, 4(2), 1-7.

Forsyth, D. R. (1980). A taxonomy of ethical ideologies. Journal of Personality and Social Psychology, 39(1), 175-184. https:// doi.org/10.1037/0022-3514.39.1.175

Harun, F. (2016). Pengaruh Sifat Machiavellian dan Love of Money terhadap Perilaku Etis Auditor. Skripsi. Sarjana Jurusan Akuntansi Fakultas Ekonomi dan Bisnis Islam UIN Alauddin Makassar. https://doi.org/10.1109/ciced.2018.8592188

Hermawan, S., \& Nurlia, W. (2017). Pengaruh Kecerdasan Terhadap Persepsi Etis Mahasiswa Akuntansi ? Intelligence on Ethical Perception of Accounting Students? E-Jurnal Akuntansi Universitas Muhammadiyah Sidoarjo, 12(1), 93103.

Liu, M. (2006). The ethical decision-making processes of professional auditors in the people' s republic of China Terms of Use The copyright of this thesis is owned by its. Lingnan University, 10, 1-68.

Malia. (2010). Pengaruh Orientasi Etika dan Pengalaman Akuntan terhadap Persepsi tentang Praktik Manajemen Laba. Skripsi. Sarjana Jurusan Akuntansi Falultas Ekonomi dan Ilmu Sosial Universitas Islam Negeri Syarif Hidayatullah.

Mudassir. (2016). Pengaruh Pengalaman Audit Terhadap Pengambilan Keputusan Etis dengan Budaya Organisasi sebagai Pemoderasi. ASSETS, Jurnal Akuntansi Dan Pendidikan, 6(1), 89-102.

Mulyani, S. (2015). Analisis Pengaruh Jenis Kelamin dan Status Pekerjaan terhadap Persepsi Etis Mahasiswa Akuntansi dengan Love of Money sebagai Variabel Intervening. Majalah Ilmu Solusi, 14(3), 1-16. https://doi.org/10.1145/3132847.3132886

Mustika, T. K., \& Jati, I. K. (2017). Pengaruh Pengalaman, Komitmen Profesional, Komitmen Organisasional, Idealisme dan Relativisme pada Etika Auditor. E-Jurnal Akuntansi Universitas Udayana, 18(3), 1971-1999.

Pradanti, N. R., \& Prastiwi, A. (2014). Analisis Pengaruh Love of Money terhadap 
Persepsi Etis Mahasiswa Akuntansi. Diponegoro Journal Of Accounting, 3(3), $1-12$.

Revita Mardawati. (2016). Pengaruh Orientasi Etis , Gender, Dan Pengetahuan Etika Terhadap Persepsi Mahasiswa Akuntansi Atas Perilaku Tidak Etis Akuntan. Jurnal Profita, 6, 1-15.

Sasongko, Budi, Basuki, \& Hendrayanto. (2007). Internal Audit dan Dilema Etika. Surabaya : STIE Perbanas.

Tahar, F. (2012). Pengaruh Diskriminasi Gender Dan Pengalaman Terhadap Profesionalitas Auditor. Skripsi. Sarjana Jurusan Akuntansi Fakultas Ekonomi Universitas Hasanuddin.

Tang, T. L., \& Chiu, R. K.-K. (2002). Costs of secondary parasitism in the facultative hyperparasitoid Pachycrepoideus dubius: Does host size matter? Entomologia Experimentalis et Applicata, 103(3), 239-248. https://doi.org/10.1023/A

Uyar, A., Kuzey, C., Güngörmüs, A. H., \& Alas, R. (2015). Influence of theory, seniority, and religiosity on the ethical awareness of accountants. Social Responsibility Journal, 11(3), 590-604. https://doi.org/10.1108/SRJ-06-20140073

Wibowo, A. (2014). Pengaruh Kode Etik Akuntan, Personal Ethical Philosophy, Corporate Ethical Value Terhadap Persepsi Etis Dan Pertimbangan Etis Auditor ( Studi Empiris pada Kantor Akuntan Publik di Jakarta ). Serat Acitya Jurnal Ilmiah, 31-48.

Widiastuti, E., \& Nugroho, M. A. (2015). Pengaruh Orientasi Etis, Equity Sensitivity, Dan Budaya Jawa Terhadap Perilaku Etis Auditor Pada Kantor Akuntan Publik Di Yogyakarta. Jurnal Nominal, IV(1), 32-48. https://doi.org/10.1145/3132847.3132886

Yeltsinta, R., Akuntansi, J., Ekonomika, F., Diponegoro, U., Prof, J., \& Sh, S. (2013). Love of Money, Ethical Reasoning, Machiavellian, Questionable Actions : the Impact on Accounting Students' Ethical Decision Making By Gender Moderation. Diponegoro Journal Of Accounting, 2(3), 1-11. 